\title{
THE USE OF SERUM CHOLINESTERASE IN SUCCINYLCHOLINE APNOEA
}

\author{
Karl Ludwig Scholler, Heinz Werner Goedde, and Heme-Gertrude Benkmann
}

THE SHORT-ACTING muscle relaxant succinylcholine is still an indispensible drug for the anaesthetist. Its effect is terminated within a few minutes through hydrolysis by serum cholinesterase (E C 3.1.1.8; pseudocholinesterase). Inherited variants of serum cholinesterase which are unable to hydrolyze succinylcholine are responsible for the occurrence of prolonged paralysis. ${ }^{1-3}$ Such variants could be demonstrated to exist in about 75 per cent of all patients with prolonged paralysis after succinylcholine." The frequency of homozygous variants which regularly lead to prolonged apnoea is about $1: 2800 .^{5}$ An unexpected neuromuscular block necessitates a longer period of artificial ventilation, usually resulting in delay in the operating schedule. On the basis of investigations by Goedde, et al. ${ }^{6}$ the Behring Company have developed a highly purified human serum cholinesterase and have marketed it in ampoules containing $45 \mathrm{mg}$ dried protein. The content of one ampoule corresponds to the amount of serum cholinesterase in approximately $500 \mathrm{ml}$ of human plasma. This paper reports on the clinical application of serum cholinesterase in patients with prolonged paralysis after succinylcholine.

\section{Patients And Methods}

Since 196815 patients, aged from 6 to 60 years, with prolonged neuromuscular block after succinylcholine have been treated with serum cholinesterase. These were patients from the daily operation list; their hypersensitivity to succinylcholine had been previously unknown. The diagnosis of a prolonged succinylcholine effect was indicated by the difference between the reflex action of the smooth muscles (not paralyzed by succinylcholine) and that of the striated muscles (paralyzed). This divergence in the reflex action could be easily observed when the central nervous system was not under the influence of high doses of anaesthetics and the reaction of the pupils to light was not impaired by opiates, ganglion blockers or miotics. A delay in the metabolism of succinylcholine was indicated if the pupils reacted to light but treacheal suction elicited no motor response. If no other muscle relaxants or cholinesterase inhibitors were involved, an atypical serum cholinesterase was assumed. Before the injection of serum cholinesterase, blood was taken from each patient and kept for biochemical genetic tests. Measurement of the enzyme activity of the serum cholinesterase was carried out with benzoylcholinechloride as substrate at $240 \mathrm{~mm}$ and $26^{\circ} \mathrm{C}$. To determine the phenotypes of

Karl Ludwig Scholler, M.D., Professor of Anaesthesiology, Institute of Anaesthesiology, University of Freiburg, FRG. Heinz Werner Goedde, Ph.D., Professor of Biochemistry, Head of the Institute of Human Genetics, University of Hamburg, FRG, and Heide-Gertrude Benkmann, Chemical Assistant, Institute of Human Genetics, University of Hamburg, FRG. 
the serum cholinesterase, dibucaine and fluoride were added to the test as inhibitors, and the "dibucaine number" (DN) and "fluoride number" (FN) were calculated. ${ }^{7,8}$

\section{Results}

In 12 of the 15 patients treated with serum cholinesterase the subsequent enzymatic examination of the serum confirmed the presence of an inherited variant of serum cholinesterase, usually the phenotype D. The clinical and enzymatic findings for these 12 patients are shown in Table I. In these patients $90 \mathrm{mg}$ of serum cholinesterase preparation was sufficient to re-establish adequate spontaneous respiration within an average of ten minutes. Succinylcholine-induced paralysis had lasted from one to three hours.

The following example shows the effect of a blood transfusion on the delayed breakdown of succinylcholine. Patient No. 12 was given $60 \mathrm{mg}$ succinylcholine during anaesthesia for osteosynthesis of a fractured femur. The blood loss during operation was one litre and this was replaced by $1000 \mathrm{ml}$ donor blood of the same group. At the end of the two-hour operation the patient's condition appeared normal and spontaneous respiration was adequate. A year later the metal splint was removed from the femur. This time the patient received succinylcholine 100 mg. The operation lasted one and a half hours. At the end of anaesthesia the awake patient showed the typical signs of incomplete motor paralysis with inadequate spontaneous respiration. A few minutes after intravenous injection of serum cholinesterase $45 \mathrm{mg}$ the patient was in full possession of his motor powers. The biochemical genetic test showed phenotype $\mathrm{D}$.

Serum cholinesterase was also effective in three patients with prolonged apnoea after succinylcholine, but here neither a lowered cholinesterase activity nor a known enzyme variant could be proved by biochemical methods.

\section{Discussion}

Former experiments by Borders ${ }^{9}$ to accelerate the destruction of succinylcholine by a fraction a human globulin containing cholinesterase (Cholase) showed no sufficient effect for clinical cases. More recently the effect and dosage of a high enriched commercial human serum cholinesterase on prolonged succinylcholine apnoea had been investigated in six volunteers. ${ }^{6}$ The results described here show that a termination of paralysis in cases of unexpected prolonged succinylcholine apnoea can be achieved clinically with the help of the commercial serum cholinesterase. Both the patient and the overburdened anaesthetist can thus be effectively relieved.

By examination of the reflexes described the delayed breakdown of succinylcholine could be quickly recognized without biochemical tests. Stimulation of the ulnar nerve with a nerve stimulator is also a helpful test to elucidate the persistent effect of succinylcholine. ${ }^{10}$ According to Horne, et al.,${ }^{11}$ signs of a phase II or dual block can be expected in prolonged neuromuscular block after succinylcholine. In one of the patients it was shown that a large transfusion of donor blood may hide a hereditary hypersensitivity to succinylcholine. 


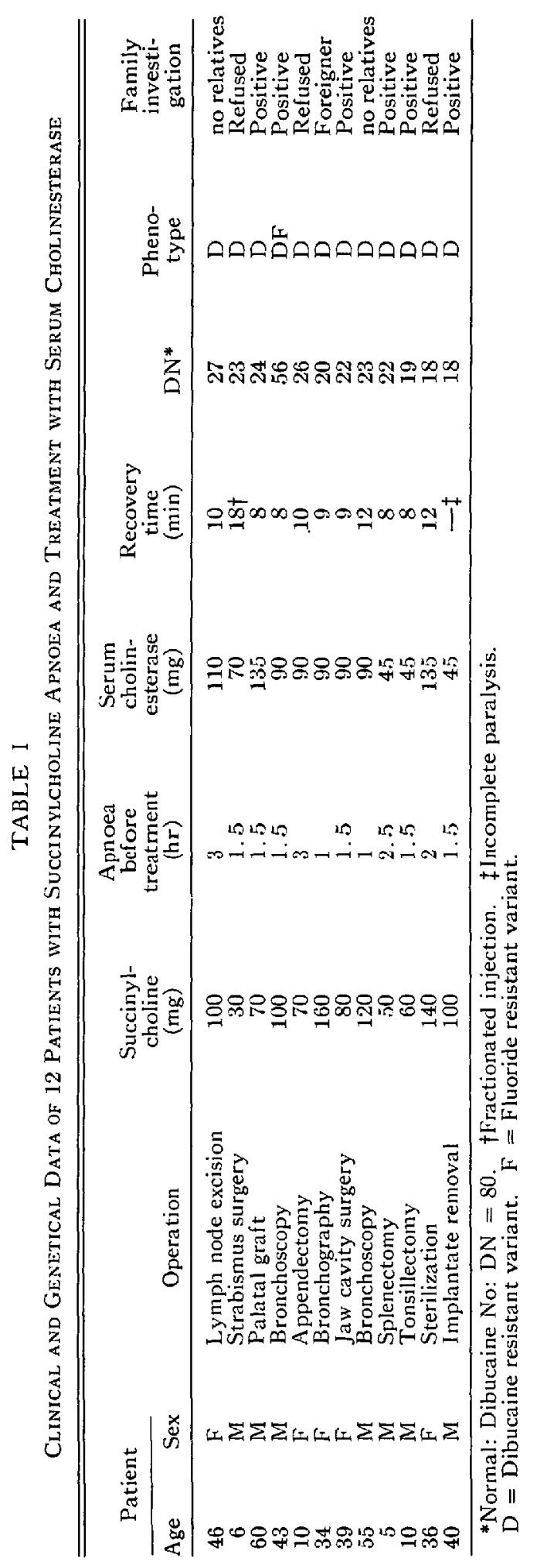


Three patients showed clinical signs of prolonged neuromuscular block after succinylcholine, but the presence of an enzyme variant could not be proved. In these three patients the paralysis was terminated by the application of serum cholinesterase. This observation supports the assumption that other unidentified variants of serum cholinesterase exist. ${ }^{12}$ Whittaker $^{13}$ succeeded in proving the presence of further hereditary serum cholinesterase variants which could not be identified with the usual methods and showed a reduced affinity for succinylcholine.

Since the activity of the injected serum cholinesterase fades away after some days, previous sensitivity to succinylcholine subsequently reappears. Serum cholinesterase is a stable protein. Preparations kept in a refrigerator for three years at $8^{\circ} \mathrm{C}$ do not lose their activity. The enzyme preparation is produced only from $\mathrm{HB}_{\mathrm{s}}$-Ag-negative human plasma. The presence of $\mathrm{HB}_{\mathrm{s}}-\mathrm{Ag}$ is excluded by the most sensitive test (RIA) in each donor. Purification of serum cholinesterase is attained by stepwise fractionated absorption. This process eliminates completely experimentally added $\mathrm{HB}_{\mathrm{s}}$-Ag. The risk of infection by this enzyme preparation seems therefore highly unlikely (personal communication of Behring Company). Unfavourable reactions to the injected human serum cholinesterase were not observed. Its rapid action and ease of application, as well as its favourable properties commend it as a suitable addition to the drugs commonly used by the anaesthetist.

\section{SUMMARY}

Fifteen patients demonstrating unexpected prolonged apnoea lasting several hours after succinylcholine have been treated by a new preparation of human serum cholinesterase.

Adequate spontaneous respiration was re-established in an average period of ten minutes after the injection. In 12 patients biochemical genetic examinations confirmed the presence of an atypical serum cholinesterase. In three patients none of the usual variants were found. It is therefore supposed that other unknown variants of serum cholinesterase exist which cannot hydrolyze succinylcholine.

The use of serum cholinesterase in succinylcholine apnoea provided considerable relief to both patient and anaesthetist.

\section{RÉSUMÉ}

Quinze malades ayant réagi à la succinylcholine par une apnée de plus d'une heure ont été traités par une cholinesterase serique d'origine humaine.

Le retour d'une respiration spontanée suffisante était obtenu en moyenne dix minutes après injection. Les examens biologiques et génètiques ont demonstré l'existence d'une cholinesterase atypique chez 12 des malades. Chez les trois autre aucune des variants connues de l'enzyme n'a été trouvée. L'hypothése de l'existence d'autres formes de cholinesterase incapables d'hydrolyser la succinylcholine est supportée. L'emploi de la cholinesterase serique humains est avantageuse pour le malade et pour l'anesthésiste. Aucune action secondaire n'a été observée. 


\section{REFERENCES}

1. Kalow, W. \& Genest, K. A method for the detection of atypical forms of human serum cholinesterase. Determination of dibucaine numbers. Canad. J. Biochem. 35: 339 (1957).

2. Goedde, H.W., Held, K.R., \& Altrand, K. Hydrolysis of succinylcholine and succcinylmonocholine in human serun. Molec. Pharmacol. 4:274 (1968).

3. Goedde, H.W. \& Altland, K. Suxamethonium sensitivity. Ann. N.Y. Acad. Sci. 179: 695 (1971).

4. Goedde, H.W., Muensch, H., Benkmann, H.G., \& Scholler, K.L. Succinyldicholin Empfindlichkeit als Folge genetisch bedingter Serumcholinesterasevarianten. Prakt. Anaesth. 11: 339 (1976).

5. Goedde, H.W., Doenicke, A., \& Altland, K. Pseudocholinesterase, Pharmakogenetik, Biochemie, Klinik. Berlin, Heidelberg, New York: Springer (1967).

6. Goedde, H.W., Althand, K., \& Schollen, K.L. Pharmakogenetische Reaktion auf Succinyldicholin: Therapie der verlängerten Apnoe. Med. Klinik 62: 1631 (1967).

7. Kalow, W. \& Davies, R.O. The activity of various esterase inhibitors towards atypical human serum cholinesterase. Biochem. Pharmacol. I: 183 (1959).

8. Harnis, H. \& Whittaker, M. Differential inhibition of human serum cholinesterase with fluoride: recognition of two new phenotypes. Nature, Lond. 191: 496 (1961)

9. Borders, R.W., Stephen, C.R., Nowill. W.K., \& Martis, R. The interrelationship of succinylcholine and the blood cholinesterase during anaesthesia. Anesthesiology 16: 401 (1955).

10. Stovneh, J. \& Stadskleiv, K. Suxamethonium apnoea terminated with commercial senumcholinesterase. Acta anaesth. scand. 20:211 (1976).

11. Horne, J.A., Watson, T.P., Gresecke, A.H., Ra J, P.P., \& Ahlgren, E.W. Prolonged apnea in an infant following the use of succinylcholine. Anesthesiology 39:545 (1973).

12. Agarwal, D.P., Schwenkengecher, S., Srivastava, L.M., \& Goedde, H.W. Spektrophotometrische Bestimmungsmethode von Serumcholinesterase - Varianten mit Succinyldicholin als Substrat. Z. Klin. Chem. u. Klin. Biochem. 13: 133 (1975).

13. WhITAKEH, M. An additional pseudocholinesterase phenotype occuring in suxamethonium apnoea. Brit. J. Anaesth. 40:579 (1968). 